\title{
BENTHIC AND SUBTERRANEAN AQUATIC OLIGOCHAETE FAUNA (ANNELIDA, OLIGOCHAETA) FROM COIBA ISLAND (PANAMÁ) AND CUBA
}

\author{
P. Rodríguez *
}

\begin{abstract}
A total of 15 taxa of aquatic oligochaetes have been identified in two collections, one of which was from Coiba island, at the National Museum of Natural Sciences (MNCN, Madrid), and the other from Cuba (leg. Dr. Ana Camacho). Morphological and systematic remarks are provided for Limnodrilus variesetosus, Pristina aequiseta forms evelinae and foreli, P. breviseta, P. osborni, and P. sima. Pristina cabacuensis Botea, 1983 and P. decui Botea, 1987 are proposed as junior synonyms of Pristina aequiseta Bourne. The taxonomy of Pristina osborni and P. sima is discussed and their independent specific status supported. The alluroidid Brinkhurstia americana is reported from Coiba island widening the known geographical distribution of the species to South and Central America.

Key words: rivers, hyporheic, caves, oligochaetes, Central America, tropical region, Tubificidae, Naididae, Alluroididae
\end{abstract}

\section{RESUMEN}

Fauna de Oligoquetos acuáticos (Annelida, Oligochaeta) bentónicos y subterráneos de la isla de Coiba (Panamá) y Cuba

Un total de 15 taxones de oligoquetos acuáticos han sido identificados en dos colecciones de la isla de Coiba del Museo Nacional de Ciencias Naturales (MNCN, Madrid) y Cuba (leg. Dra. Ana Camacho). Se aportan notas morfológicas y sistemáticas para las especies Limnodrilus variesetosus, Pristina aequiseta formas evelinae y foreli, P. breviseta, P. osborni y P. sima. Pristina cabacuensis Botea, 1983 y P. decui Botea, 1987 son propuestas como sinónimos de Pristina aequiseta Bourne. Se discute la taxonomía de Pristina osborni y P. sima y se apoya su estatus de especies independientes. El alluroidido Brinkhurstia americana se cita en la isla de Coiba ampliando la distribución actual de la especie a America Central y del Sur.

Palabras clave: ríos, hiporreos, cuevas, oligoquetos, Centroamérica, región tropical, Alluroididae, Tubificidae, Naididae.

\section{Introduction}

In the present work, new data from two collections of oligochaete worms from both hyporheic and running waters in Coiba island and from subterranean waters in Gibara, Cuba, are provided. Located in the Pacific Ocean, close to the west shore of
Panamá, Coiba island is exceptionally unaltered because it has been a prison since 1920 (GarcíaValdecasas et al., 1997). The National Museum of Natural Sciences (MNCN) in Madrid, Spain, is currently studying the freshwater fauna of Coiba as an example of unaltered, neotropical, small-sized rivers and they have generously made the aquatic

* Dpto. Zoología y Dinámica Celular Animal. Facultad de Ciencias. Universidad del País Vasco UPV/EHU. Apdo. 644. Bilbao, 48080. Spain. e-mail: ggprorop@lg.ehu.es 
oligochaete collection available for identification. This paper also includes descriptions of oligochaete worms from subterranean waters in Cuba, sampled by Dr. Ana Camacho who has also kindly sent me the oligochaete worms for determination.

\section{Study sites and methods}

The studied localities in Coiba island and Cuba, with sampling data and the reference sampling codes in the collections at the MNCN (Museo Nacional de Ciencias Naturales) are listed below. See Fig. 1 for the geographical location of the two study areas.

Collection from Coiba island (Panamá). Except for restricted agricultural activity, the land of Coiba island has not been influenced by human activity (García-Valdecasas et al., 1997). The island presents a well-preserved tropical forest with a large number of small rivers and streams, in which no evidence of organic pollution has been detected. Environmental variables and sampling procedures are described in detail by García-Valdecasas et al. (1997). The studied sites show conductivity values within the range of $125-450 \mu \mathrm{S} \mathrm{cm}^{-1}$, water temperatures between $24-26^{\circ} \mathrm{C}$ and dissolved oxygen over $6.4 \mathrm{mg} \mathrm{l}^{-1}$. The worms were fixed in $4 \%$ formaldehide or $70 \%$ ethanol and conserved in $70 \%$ ethanol. The collection is maintained in the National Museum of Natural Sciences (MNCN) in Madrid and the Department of Zoology of the University of the Basque Country (UPV/EHU).

1. JI1K: Juncal River. Left and right margins. 1. Kick sampling. 4.VIII.1994.

2. E12(2): Juncal River. 28.VIII.1998.

3. CXK: Cerro de la X. Kick sampling. 5.VIII.1994.

4. ARE 1S1: Escondido River, 1. Surber sampler. 8.VIII.1994.

5. ARE 1S2: Escondido River, 1. Surber sampler. 8.VIII.1994.

6. ARE 2S2: Escondido River, 2. Surber sampler. 8.VIII.1994.

7. ARE 4S2: Escondido River, 4. Surber sampler. 8.VIII.1994.

8. ARE 4I: Escondido River, 4. Karaman-Chapuis. 8.VIII.1994.

9. BRE 3K: Escondido River, 3. Kick sampling. 10.VIII.1994.

10. BRE 3I. Escondido River, 3. Karaman. 20.VIII.1994.

11. BRE 4K: Escondido River, 4. Kick sampling. 10.VIII.1994.

12. BRE 6K: Escondido River, 6. Kick sampling. 10.VIII.1994.

13. BRE 7K: Escondido River, 7. Kick sampling. 10.VIII.1994.

14. BRE 9K: Escondido River, 9. Kick sampling. 10.VIII.1994.

15. BRE 10K: Escondido River, 10. Kick sampling. 10.VIII.1994

16. ARN1I1. Negro River, 1. Karaman-Chapuis 1. 11.VIII.1994.

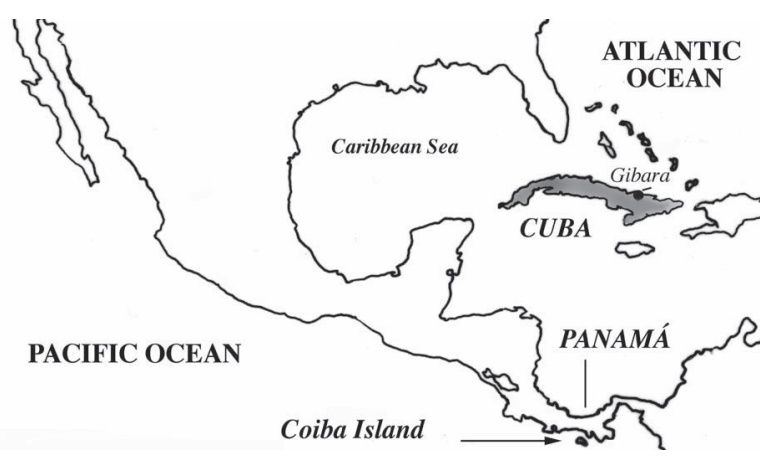

Fig. 1.- Location of the two study regions in Central America (Coiba island and Cuba).

Fig. 1.- Localización de las dos áreas de estudio (isla de Coiba y Cuba) en Centro-América.

17. ARN1I2. Negro River, 1. Karaman-Chapuis 2. 11.VIII.1994.

18. ARN2I. Negro River, 2. Karaman-Chapuis. 11.VIII.1994.

19. RB4K. Boa River, 4. Karaman-Chapuis. 13.VIII.1994.

20. SC2I. Santa Clara River, 3. Karaman-Chapuis. 14.VIII.1994.

21. SC2K. Santa Clara River, 3. Kick sampling. 14.VIII.1994.

22. CA1K: Santa Cruz River A, 1. Kick sampling. 16.VIII.1994

23. PE1K: Punta Esquina River, 1. Kick sampling. 17.VIII.1994.

24. QE1I. Quebrada Espave. Jicarón island, Panamá. Karaman-Chapuis. 18.VIII.1994

25. BRN1K1: Negro River, 1. Kick sampling, 1. 19.VIII.1994.

26. CG1K: Catival River, 1. Kick sampling. 22.VIII.1994.

27. SJ1K: San Juan River, 1. Kick sampling. 22.VIII.1994.

28. SJ1I: San Juan River, 1. Karaman-Chapuis. 22.VIII.1994.

29. BPH1I. Playa Hermosa River, 1. Karaman-Chapuis. 23.VIII.1994.

30. SCEK: Santa Cruz River. At $500 \mathrm{~m}$. of the mouth of the river, freshwater. Kick sampling. 21.VIII.1994.

Collection from Gibara (Cuba) (Dr. Ana Camacho, $M N C N$ ).

31. Tanque Azul, Caletones, Gibara. Mixture of freshwater and brackish water. Samples were collected by disturbing the bottom sediment which was sieved through a $125 \mu \mathrm{m}$ mesh.12.IV. 1995.

32. Cacoyuguín River. Karaman-Chapuis. Candelaria. 14.IV.1995.

33. Cueva del Agua, Gour 1. Candelaria. Worms sampled as in site 31. 14.IV.1995.

34. Cueva del Agua, Gour 3. Candelaria. Worms sampled as in site 31. 14.IV.1995.

35. Cueva del Agua, Gour 3. Candelaria. Worms sampled as in site 31. 13.IV.1995. 


\section{Systematic part}

HAPLOTAXIDAE

RECORDS: site 8 ( 1 ind. immature)

\section{LUMBRICULIDAE}

RECORDS: site 15 ( 1 ind. immature)

\section{TUBIFICIDAE}

Monopylephorus camachoi Rodriguez, 1999

RECORDS: site 30 (10 ind.), type locality of the species (Rodriguez, 1999)

Limnodrilus variesetosus Brinkhurst, 1979 (Fig. 2) RECORDS: site 32 (10 ind.)

DESCRIPTION: Immature worms. Triangular prostomium. Bifid chaetae. Dorsal bundles 2-4 chaetae, usually 4; ventral bundles 3-6 chaetae. In anterior segments, ventral chaetae thicker and longer than dorsal of the same segment. Anterior dorsal chaetae from II to $\mathrm{V}$ with upper teeth about 1.2 to 1.6 times longer than lower, being of about the same length from VI or VII, backwards. Ventral chaetae of these same segments with upper teeth about 2 to 3.5 times longer than lower, gradually reducing the difference from segment VI backwards. Posterior segments have thinner chaetae, with the upper teeth equal or shorter, and thinner than the lower. The position of the nodulus in both dorsal and ventral chaetae goes from median (distal portion/total length: 0.48-0.50) in the anterior segments to distal (up to 0.40) in the most posterior segments.

REMARKS: Among the American Limnodrilus species, both $L$. variesetosus Brinkhurst, 1979 and L. rubripenis Loden, 1977 show enlarged ventral chaetae with very long upper teeth in some segments of the anterior part of the body. The examined material has been identified as $L$. variesetosus because of the presence of the enlarged chaetae in the first segments II (III) to V, instead of IV (V) to IX, characteristic of the L. rubripenis. Chaetae in the new material from Cuba and in the Jamaican population of $L$. variesetosus are basically similar (Fig. 2A, B and C).

Brinkhurst and Wetzel (1984) considered this species as a possible variant of L. udekemianus. Brinkhurst and Marchese (1989) also discussed the possible synonymy of both species. Compared with

Table 1.- Chaetae characteristics from one immature individual of Limnodrilus variesetosus (from Candelaria, Cuba), and comparisons with L. udekemianus from Spain. Abbreviations: L, lower; U, upper.

Tabla 1.- Caracteristicas de las quetas de un individuo inmaduro de Limnodrilus variesetosus (de Candelaria, Cuba) y comparación con L. udekemianus (de País Vasco, España). Abreviaturas: L, inferior; U, superior.

\begin{tabular}{|c|c|c|c|c|c|c|c|}
\hline Segment & II & III & IV & $\mathbf{V}$ & VI & VII & Posterior \\
\hline \multicolumn{8}{|l|}{ dorsal } \\
\hline length $(\mu \mathrm{m})$ & 46 & 56 & 66 & - & 66 & 75 & $48-64$ \\
\hline$\varnothing(\mu \mathrm{m})$ & 3.0 & 3.7 & 3.7 & 3.7 & 3.7 & 3.7 & 3.0 \\
\hline Teeth U/L $(\mu \mathrm{m})$ & $6.2 / 4.3$ & $6.8 / 5.0$ & $6.8 / 5.0$ & $6.8 / 4.3$ & $3.7-5 / 4.3$ & $4.3 / 4.3$ & $4.3-5 / 4.3-5$ \\
\hline \multicolumn{8}{|l|}{ ventral } \\
\hline length $(\mu \mathrm{m})$ & 48 & 77 & 82 & 80 & 78 & 70 & $48-64$ \\
\hline$\varnothing(\mu \mathrm{m})$ & 3.0 & 5.0 & 5.0 & 4.3 & 4.3 & 4.3 & 3.7 \\
\hline \multirow[t]{2}{*}{ Teeth U/L $(\mu \mathrm{m})$} & $5.6-6.8 / 3.1$ & $\underline{6.2-8.2}$ & $\underline{8.7-9.0}$ & $7.4 / 3.1$ & $5.6 / 4.3$ & $5.6 / 4.3$ & $3.6-5 / 4.3-5$ \\
\hline & & $2.5-3.1$ & $2.5-3.1$ & & & & \\
\hline
\end{tabular}

\begin{tabular}{|c|c|c|c|c|}
\hline \multirow[b]{2}{*}{ Chaetae teeth } & \multicolumn{2}{|c|}{ L. udekemianus } & \multicolumn{2}{|c|}{ L. variesetosus } \\
\hline & Anterior chaetae & Posterior chaetae & Anterior chaetae & Posterior chaetae \\
\hline \multicolumn{5}{|l|}{ length ( $\mu \mathrm{m})$} \\
\hline Upper tooth & $9.3-11.6$ & $5.8-7.5$ & $5.6-9.0$ & $3.6-5.0$ \\
\hline Lower tooth & $3.5-4.6$ & 4.6 & $2.5-5.0$ & $4.3-5.0$ \\
\hline \multicolumn{5}{|l|}{ width $(\mu \mathrm{m}) *$} \\
\hline Upper tooth & $2.9-4.6$ & 3.5 & $1.8-3.2$ & 1.4 \\
\hline Lower tooth & $2.3-2.9$ & 3.5 & $1.6-1.8$ & $2.0-2.3$ \\
\hline
\end{tabular}

* Width of chaetae teeth was measured at the base of the tooth. 

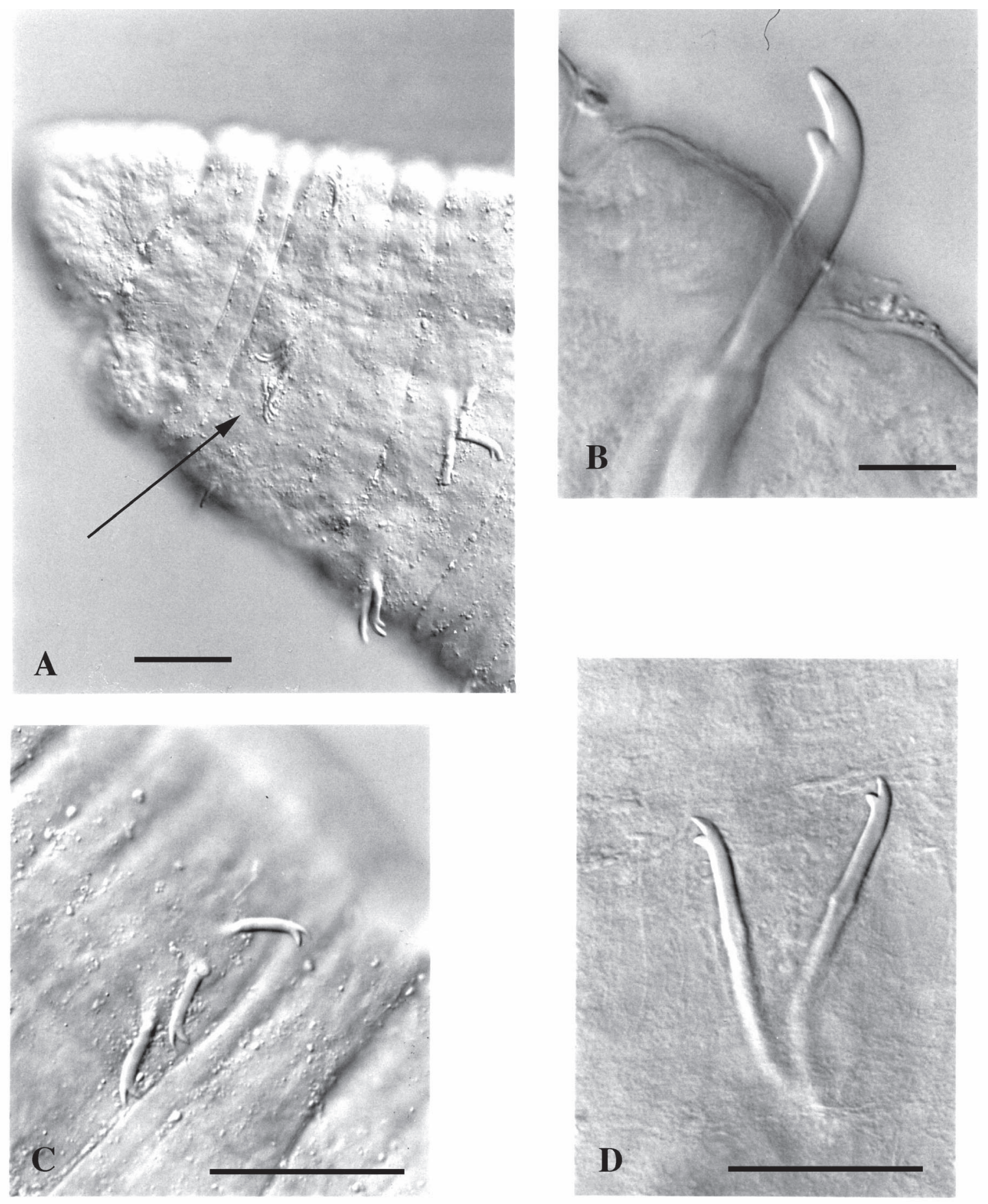

Fig. 2.- Limnodrilus variesetosus. A. Prostomium, segments II and III (the arrow indicates the position of ventral chaetae in segment II). B. Enlarged ventral chaeta in segment III similar to anterior chaetae in L. udekemianus . C. Posterior chaetae. D. L. udekemianus, posterior chaetae. Scale bars: $50 \mu \mathrm{m}$ in $\mathrm{A}, \mathrm{C}$ and $\mathrm{D}, 10 \mu \mathrm{m}$ in B.

Fig. 2.- Limnodrilus variesetosus. A. Prostomio, segmentos II y III (la flecha incica la posición de las quetas ventrales en el segmento II). B. Queta ventral en segmento III. C. Quetas posteriores. D. L. udekemianus, quetas posteriores. Escala: $50 \mu \mathrm{m}$ en A, C and $\mathrm{D}, 10 \mu \mathrm{m}$ en $\mathrm{B}$. 
L. variesetosus, L. udekemianus (studied in Spanish specimens) can be distinguished by the teeth proportions in chaetae which always have the upper tooth longer than the lower, in both anterior and posterior bundles (Table 1). In both species, the upper tooth is thicker than the lower in the anterior segments (Fig. 2 B). However, in L. udekemianus posterior chaetae have upper and lower teeth of the same width (Fig. 2 D), whereas in L. variesetosus the upper tooth is thinner than lower (see Fig. $2 \mathrm{C}$ and Brinkhurst, 1979). The scales in the original drawing (Fig. 1, in Brinkhurst, 1979) are necessarily wrong for the chaetae.

The existence of variants in the size of chaetae has been demonstrated in other tubificid species related to ionic characteristics of water (form grandiseta of Tubifex tubifex, see Rodríguez and Armas, 1983). Environmental data from the site (GarcíaValdecasas et al., 1997) do not suggest any apparent characteristic different from a typical freshwater site. Since the worms of our collection are immature, the contribution to clarify the taxonomic status of this species is limited.

\section{Undetermined Tubificidae}

RECORDS: site 10 (1 immature), 17 (several fragments), 25 (1 immature), 26 (1 immature), 31 (1 immature and 1 mature Rhyacodrilinae, 7 immature Phallodrilinae)

\section{NAIDIDAE}

Stephensoniana trivandrana (Aiyer, 1926) (Fig. 3)

RECORDS: site 1 (1 ind.), 26 (1 ind.)

DESCRIPTION: 1 to $1.6 \mathrm{~mm}$ long. Diameter of the body $142 \mu \mathrm{m}$ in IV and $164 \mu \mathrm{m}$ in IX. Number of segments 11 and 18 . Prostomium very short, $40 \mu \mathrm{m}$ long (Fig. 3A). The body wall is $5-8 \mu \mathrm{m}$ thick and it is incrusted by foreign material, not densely covered in the anterior part and very dense in the posterior part of the body.

Dorsal chaetae start in segment II. Dorsal bundles consist of 1-3 smooth hair chaetae and 1-3 thin needles, suddenly tapering towards the distal end. Two hair chaetae per bundle in the first segments (115-128 $\mu \mathrm{m}$ long), 3 in the following V to VII segments (144-150 $\mu \mathrm{m}$ long), decreasing to only 1 in the last segments of the body (120-152 $\mu$ m long). Hair chaetae are about $2 \mu \mathrm{m}$ thick at their base, close to the tegument. Needles, 40 to $43 \mu \mathrm{m}$ long (ca. $1 \mu \mathrm{m}$ thick), simple-pointed, with a distal, inconspicuous nodulus at about $1 / 4$ of the distal apex.

Ventral bundles with 3 bifid chaetae, decreasing to 1-2 in most posterior segments, with the nodulus proximal, at about one third of the base. Ventral chaetae 62-64 $\mu \mathrm{m}$ long in anterior segments, up to $85 \mu \mathrm{m}$ in middle and posterior segments. Upper tooth grows backwards, being 1.6 to 2 times longer
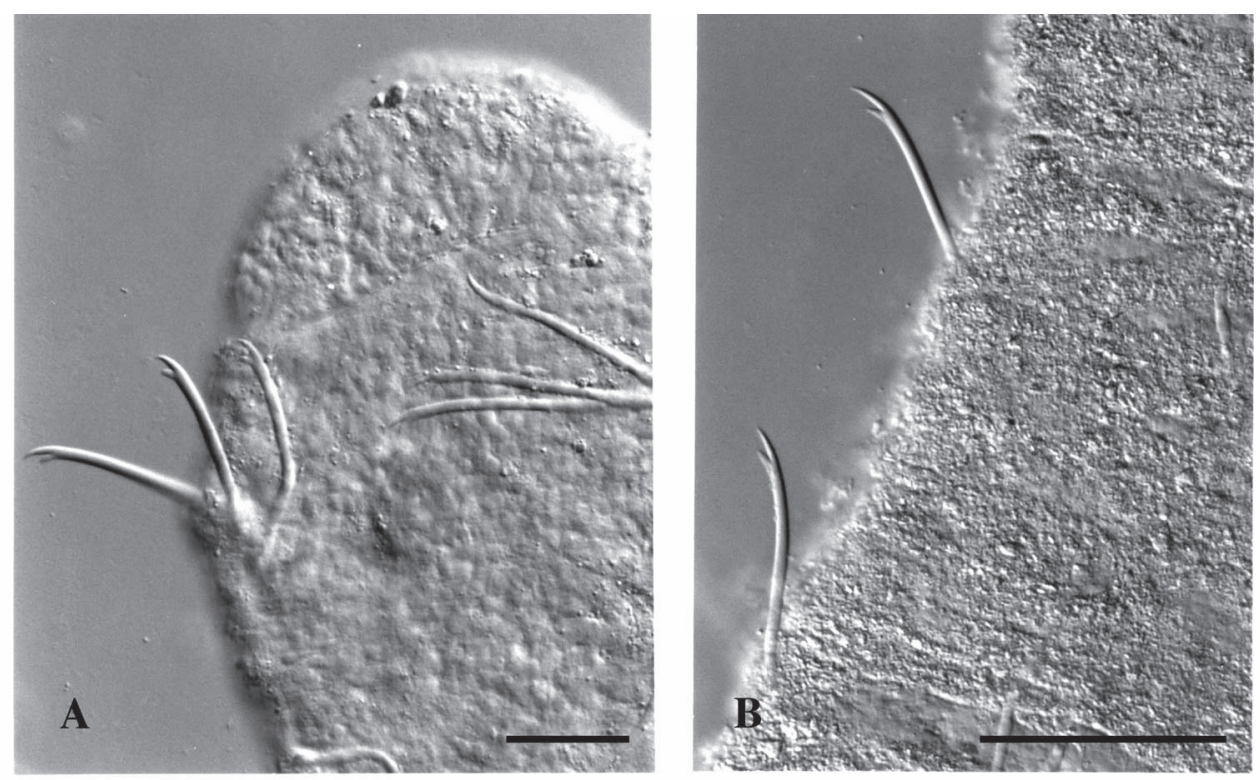

Fig. 3.- Stephensoniana trivandrana. A. Prostomium and chaetae of segment II. B. Posterior ventral chaetae. Scale bar: $50 \mu \mathrm{m}$.

Fig. 3.- Stephensoniana trivandrana. A. Prostomio y quetas del segmento II. B. Quetas posteriores ventrales. Escala: $50 \mu \mathrm{m}$. 
Table 2.- Length of chaetae of Stephensoniana trivandrana, from several sources.

Tabla 2.- Longitud de las quetas de Stephensoniana trivandrana, extraído de varias fuentes.

\begin{tabular}{lccc}
\hline Source & Hairs & $\begin{array}{c}\text { Length }(\boldsymbol{\mu m}) \\
\text { Needles }\end{array}$ & Ventral setae \\
\hline Sperber (1948) & $120-145$ & $\begin{array}{c}38-50 \\
\text { Within Sperber's limits }\end{array}$ & $67-90$ \\
Dumnicka (1986) & $135-145$ & $29-34$ & $72-78$ \\
Grimm (1986)* & 175 & 38 & 73,81 \\
Grimm (1990) & $140-215$ & $31-44$ & $57-102$ \\
This study & $115-150$ & $40-43$ & $62-85$ \\
\hline
\end{tabular}

* mean values.

than lower in anterior segments and up to 3 times longer in the posterior segments.

REMARKS: The chaetae measurements are within the range reported in the literature (Table 2). In America, the species has been observed in several localities (USA: see Brinkhurst 1986; Mexico: see Brinkhurst and Marchese 1989), Surinam (Harman, 1974), Haiti (Dumnicka, 1986) and Argentina (Di Persia, 1980). The finding in Panamá confirms the extensive presence of this species in American freshwater habitats. The species has not been reported in Europe and Australia, so far.

\section{Pristina aequiseta Bourne, 1891 form evelinae}

RECORDS: site 5 (1 ind.)

DESCRIPTION: Number of segments, 21. Diameter of the body in the VIII segment, $83 \mu \mathrm{m}$. Prostomium rounded (40 $\mu \mathrm{m}$ long), prolonged into a proboscis (40 $\mu \mathrm{m}$ long) in fixed material. Stomachal dilatation in segment VIII.

Dorsal bundles formed by one "hairy" hair chaeta, increasing in length in the anterior segments of the body (from 85 to $126 \mu \mathrm{m}$ ) and decreasing to 111 $\mu \mathrm{m}$, backwards. One needle per dorsal bundle, 28$31 \mu \mathrm{m}$ long and about $1.5 \mu \mathrm{m}$ thick, bifid, with equal tiny teeth, of about $1 \mu \mathrm{m}$ long.

Ventral chaetae, 3-4 per bundle in segments II to $\mathrm{IV}$, one giant chaetae in $\mathrm{V}, 5-6$ in the following segments, and (2) 3-4 per bundle in the posterior part of the body. Ventral chaetae of segment II are longer than the following ones, except for the giant chaeta (see Table 3 ). Chaetae of segment II are thinner $(1.5 \mu \mathrm{m})$ than the following ones $(2 \mu \mathrm{m})$; the giant chaetae reach a thickness of $4.8 \mu \mathrm{m}$. The nodulus of ventral chaetae in segment II is proximal (distal portion /total length $=0.67$ ), median in the next anterior segments, with a tendency to a more distal position in the posterior segments (up to 0.41$)$. Upper tooth $(\mathrm{U})$ longer than lower $(\mathrm{L})$ in anterior segments $(\mathrm{U} / \mathrm{L}=2.5-3.0 / 2.0 \mu \mathrm{m})$, changing to an equal length backwards $(2.2 / 2.2 \mu \mathrm{m})$.

REMARKS: Pristina evelinae Marcus, 1943 was considered a probable synonym of $P$. aequiseta Bourne, 1891 by Brinkhurst (1971). After the examination of more than one thousand individuals, Harman (1974) reported an overlapping of chaetae measurements in both species and he proposed the synonymy of the species. As $P$. evelinae, this form has been previously reported in Surinam (Harman, 1974), Argentina (Di Persia, 1980; Pujals, 1985), Bolivia (Martinez-Ansemil and Giani, 1986), Brazil (Marcus, 1943, 1949) and in hyporheic waters of Venezuela (Botea, 1987).

\section{Pristina aequiseta Bourne, 1891 form foreli}

ReCORDS: site 1 ( 1 ind.), 3 ( 2 ind.), 20 ( 2 ind.), 28 (5 ind.)

DESCRIPTION: The diameter of the body in segment VIII is 151-158 $\mu \mathrm{m}$. Prostomium rounded (57 $\mu \mathrm{m}$ long), prolonged into a proboscis (79-95 $\mu \mathrm{m}$ long) in fixed material. Dorsal bundles present one or two "hairy" hair chaetae, increasing in length in the anterior segments of the body, from 111-136 $\mu \mathrm{m}$ in II, to $284-294 \mu \mathrm{m}$ in VI. In posterior segments, hair chaetae reduce their length down to 66 $\mu \mathrm{m}$ (Table 3). Hair chaetae are thinner in II (1.2-1.6 $\mu \mathrm{m})$ than in the remaining segments $(2-3 \mu \mathrm{m})$. One or two needles per dorsal bundle, 37-58 $\mu \mathrm{m}$ long and ca. $1.5 \mu \mathrm{m}$ thick, increasing their length in the anterior segments; bifid, with equal or unequal tiny teeth, ca. 0.5-1 $\mu \mathrm{m}$ long.

Ventral chaetae 3-4 (5) per bundle in anterior segments, and occasionally 1 or 2 per bundle, backwards. Anterior chaetae with proximal nodulus (distal portion /total length $=0.51-0.57$ ) in segment II and gradually more distal in the following segments. Upper (U) tooth longer than lower (L) in 
Table 3.- Chaetae characteristics of one individual of Pristina aequiseta form evelynae, and three individuals of Pristina aequiseta form foreli, from Coiba island, Panamá.

Tabla 3.- Características de las quetas de un individuo de Pristina aequiseta forma evelynae, y 3 individuos de Pristina aequiseta forma foreli, de la isla de Coiba, Panamá.

\begin{tabular}{lccccccc}
\hline Segment & II & III & IV & V & VI & VII & Posterior \\
\hline $\begin{array}{l}\text { Pristina aequiseta form evelynae } \\
\text { Hair-chaetae }\end{array}$ & 85 & 95 & 126 & 123 & 129 & 126 & down to 111 \\
$\begin{array}{l}\text { Ventral chaetae } \\
\text { number }\end{array}$ & 3 & $3-4$ & 4 & 1 & 5 & 6 & (2) $3-4$ \\
$\quad \varnothing \mu \mathrm{m}$ & 1.6 & 2 & 2 & 4,8 & 2 & 2 & 2 \\
$\quad$ length $\mu \mathrm{m}$ & 46 & 34 & 34 & 64 & 35 & 37 & $37-38$ \\
\hline Pristina aequiseta & form foreli & & & & & & \\
Hair-chaetae & $111-164$ & $180-227$ & $190-259$ & $272-275$ & $284-294$ & $246-272$ & $66-240$ \\
Needles & 37 & $40-51$ & 53 & $56-58$ & 54 & $48-50$ & $39-48$ \\
Ventral chaetae & $42-46$ & 43 & $43-50$ & $43-50$ & $51-54$ & $51-53$ & $48-54$ \\
\hline
\end{tabular}

anterior segments $(\mathrm{U} / \mathrm{L}=3.7 / 2.5 \mu \mathrm{m})$, changing to an equal length in the median part of the body $(2.5-$ $3.1 \mu \mathrm{m})$, and shorter than the lower in the most posterior segments $(\mathrm{U} / \mathrm{L}=2.4 / 3.0 \mu \mathrm{m})$.

REMARKS: The "hairy" appearance of hair chaetae is not an easy character to observe, even under a magnification of x1250. Harman (1966) did not see serration in the Mississippi material, and he expressed some doubts about its reliance (Harman, 1974). Ventral chaetae in segment II are not, or just slightly, differentiated in length and thickness from the other ventral chaetae. This fact has previously been reported in populations examined by Dumnicka (1986) in the Caribbean Islands.

Pristina aequiseta, forms foreli and aequiseta have been reported in several localities in the Caribbean region: the West Indies and Haiti (Dumnicka, 1986), Surinam (Harman,1974), Venezuela (Botea, 1987), as well as in other parts of America (Costa Rica and Nicaragua: Harman,

Table 4.- Several morphological features of Pristina aequiseta forms foreli and aequiseta from different: sources. Abbreviations: L, lower tooth, s, number of segments, U, upper tooth.

Tabla 4.- Varios caracteres morfológicos de Pristina aequiseta formas foreli y aequiseta, extraído de diversas fuentes. Abreviaturas: L, diente inferior, s, número de segmentos, $\mathrm{U}$, diente superior.

\begin{tabular}{|c|c|c|c|c|c|}
\hline Source & $\mathbf{s}$ & Hairs $(\mu \mathrm{m})$ & Needles $(\mu \mathrm{m})$ & Needle teeth $\mathrm{U} / \mathrm{L}(\mu \mathrm{m})$ & Ventral chaetae \\
\hline Sperber (1948) foreli & $20-26$ & $150-480$ & $38-63$ & $1.5 / 1.5$ & $44-65$ \\
\hline Sperber (1948) aequiseta & $18-23$ & $120-270$ & $30-69$ & $1.5 / 1.5$ & $42-70$ \\
\hline Sperber $(1948) *$ & - & $118-362$ & $23-69$ & - & $32-62$ \\
\hline Dumnicka (1986) & - & $105-390$ & $34-48$ & - & $32-49$ \\
\hline Ercolini (1969) & $25-26$ & $100-198$ & $37-39$ & - & $34-53$ \\
\hline Ercolini (1970) & 15 & $115-261$ & $45-72$ & $1.4 / 2.7$ & $45-53$ \\
\hline $\operatorname{Grimm}(1986)^{* *}$ & - & 144 & 39 & - & $45-54$ \\
\hline Grimm (1990) & $15-26$ & 104-189 & $30-51$ & - & $39-75$ \\
\hline Harman (1973) & - & $110-210$ & $28-41$ & - & $41-53$ \\
\hline Harman (1974) & - & $80-190$ & $21-40$ & - & $29-52$ \\
\hline Harman et al. (1979) & - & $150-234$ & $25-37$ & - & $42-52$ \\
\hline Harman et al. (1988) & - & $118-237$ & $30-36$ & - & $35-70$ \\
\hline Marcus (1943) & $18-23$ & $90-180$ & - & $\approx 0.5 \S$ & $40-45$ \\
\hline This study & 20 & $66-294$ & $37-58$ & $1.0 / 0.5-1.0$ & $43-54$ \\
\hline P. cabacuensis Botea, 1983 & - & $140-385$ & $52-70$ & 0.52 & $35-60$ \\
\hline P. decui Botea, 1987 & 22 & $105-210$ & - & - & - \\
\hline
\end{tabular}



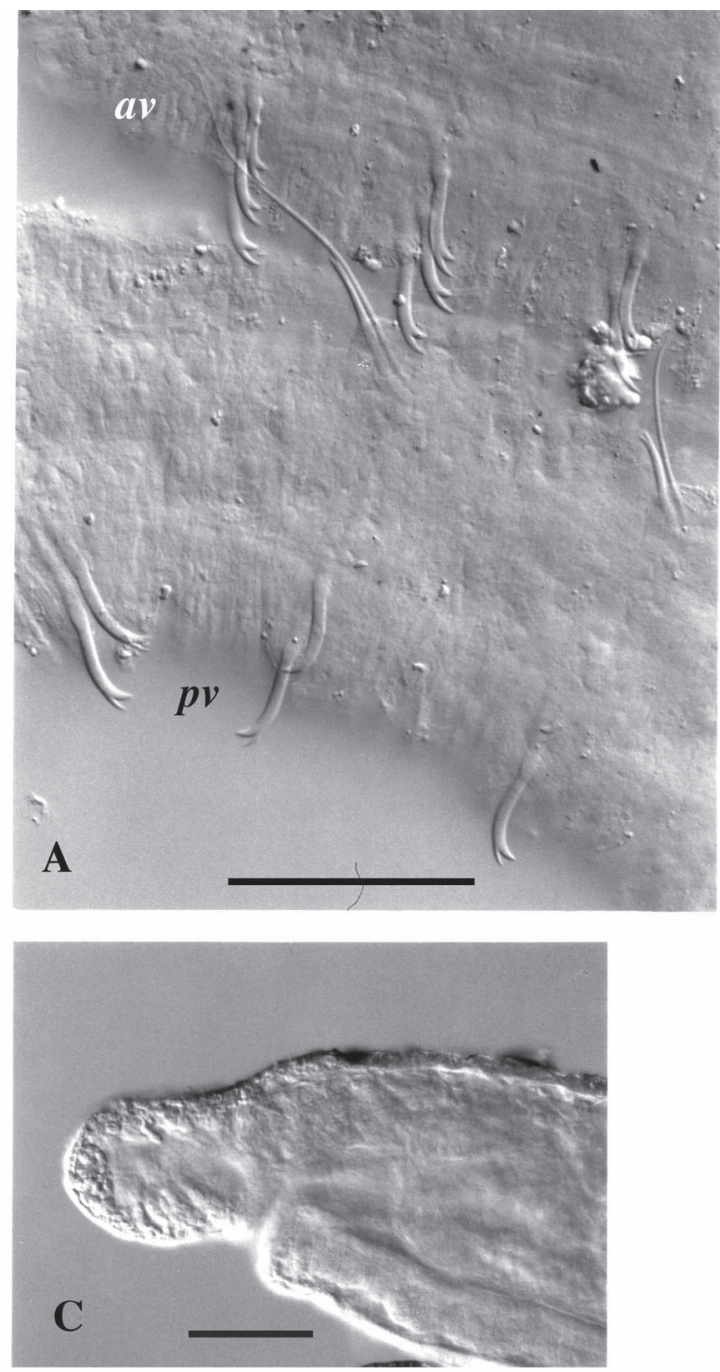
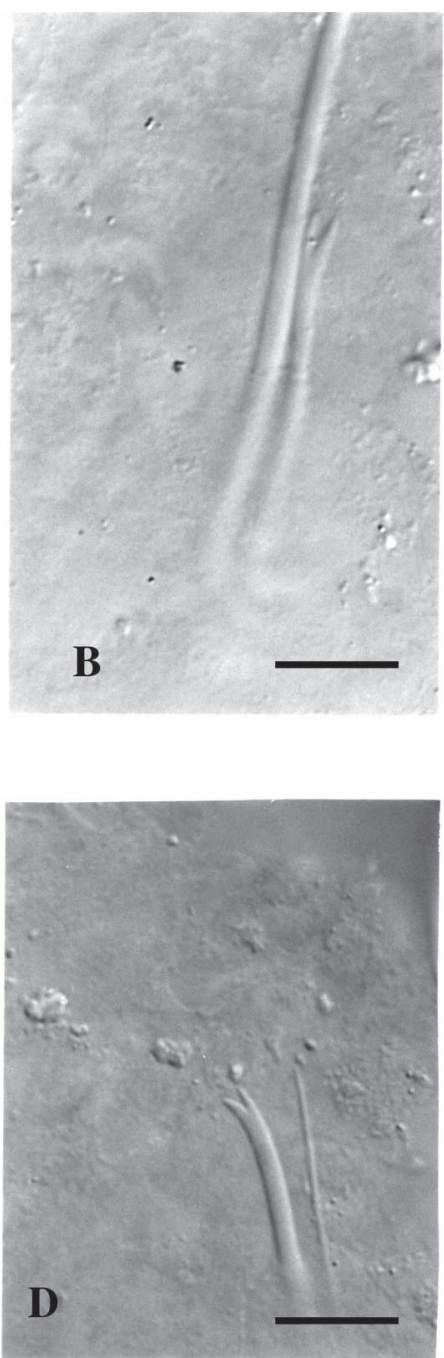

Fig. 4.- Pristina breviseta. A. Anterior ventral chaetae above, and posterior chaetae below. B. Anterior needle. C. Prostomium. D. Posterior needle. Scale bars: $50 \mu \mathrm{m}$ in A and C, $10 \mu \mathrm{m}$ in B and D.

Fig. 4.- Pristina breviseta. A. Quetas ventrales anteriores arriba, quetas posteriores abajo. B. Aguja anterior. C. Prostomio. D. Aguja posterior. Escala: $50 \mu \mathrm{m}$ en A y C, $10 \mu \mathrm{m}$ en B y D.

1982; Ecuador: Coates and Stacey, 1994; Guyana: Stacey and Coates, 1996; Texas: Harman, 1973, Harman et al., 1979; Great Lakes: Spencer, 1980; Brazil: Marcus, 1943; Argentina: Pujals, 1985; Chile: Gluzman, 1990; Peru: Harman et al., 1988; Bolivia: Martinez-Ansemil and Giani, 1986; Colombia is also reported in Brinkhurst and Marchese, 1989).

In Cuba and Venezuela, Botea described 5 new Pristina species, and among them Pristina cabacuensis Botea, 1983 and P. decui Botea, 1987 are probably synonyms of $P$. aequiseta. $P$. cabacuensis was described from specimens sampled from 2 localities in Cuba (one specimen in brackish waters). The author discussed their resemblance with $P$. foreli and $P$. aequiseta. We have incorporated the information of chaetotaxy of the species in Table 4, and their range of values is within those reported for $P$. aequiseta. The author stated that the most significant difference of the species is the length of the needle teeth which is described as long; however, their length is only $0.5 \mu \mathrm{m}$, thus 
they are in fact very short. Other supposed differences relate to the number of ventral chaetae per bundle, 2-4 forwards and 2-3 (5) backwards, but this is within the range of variation known for $P$. aequiseta (form foreli) (see Sperber, 1948). In my opinion, the only significant difference with $P$. aequiseta is that the teeth of ventral chaetae in anterior segments are of equal length.

Pristina decui was described from Venezuela hyporheic fauna by Botea (1987). The author compares the new species with $P$. aequiseta. The description of the species is very poor and does not provide information regarding measurements of needles and ventral chaetae. The absence of serration in hair chaetae of $P$. decui could be due to both the difficulty to see this character depending on the orientation, and also to its variability (Harman et al., 1988). The position of the stomach dilatation in IV or V is consistent with the possibility of an individual regenerating from fission, since the stomach dilatation in the Pristina genus is usually found in VI to VIII. Again in this case, the only significant difference with $P$. aequiseta (form foreli) is in my opinion the length of the teeth in the anterior ventral chaetae. In this respect, it is interesting that the specimens described by Dumnicka (1986) as $P$. foreli from the West Indian Islands in the Caribbean region also showed a very slight difference in the length of the teeth of anterior ventral chaetae.

Pristina breviseta Bourne, 1891 (Fig. 4)

RECORDS: site 14 (1 ind.)

DESCRIPTION: 27 segments. Diameter of the body in segment VIII, $126 \mu \mathrm{m}$. Prostomium rounded, longer than wide at its base (79 $\mu \mathrm{m}$ long, 57 $\mu \mathrm{m}$ wide), not prolonged into a proboscis (Fig. 4C).

One smooth hair chaeta, thinner in segment II (ca. $1.0 \mu \mathrm{m})$ than in the following segments $(1.5-2$ $\mu \mathrm{m})$. The length of hair chaetae increases at the anterior region of the body (76 to $221 \mu \mathrm{m}$ ), and in the posterior region they gradually shorten, down to $48 \mu \mathrm{m}$. One needle per dorsal bundle (30-48 $\mu \mathrm{m}$ long, $1.2 \mu \mathrm{m}$ thick), bifid, with equal teeth, 3.0-5.0 $\mu \mathrm{m}$ long in segments II to VII (Fig. 4B), 2.5-3.0 $\mu \mathrm{m}$ in segments VIII to X, and 2.0- $2.2 \mu \mathrm{m}$ in the posterior segments of the body. Posterior needles show unequal short teeth, with upper teeth slightly thinner and shorter than lower (Fig. 4D).

Ventral chaetae 3 per bundle in the anterior and median segments, decreasing to 1-2 in the posterior part of the body. In the anterior segments, ventral chaetae gradually increase in length backwards $(48-58 \mu \mathrm{m})$, and gradually shorten towards the posterior part of the body $(48-53 \mu \mathrm{m})$. The thickness of ventral chaetae is similar all along the body (2.5 $\mu \mathrm{m})$, although slightly thinner in the most posterior bundles. The nodulus of ventral chaetae in segment II is nearly median, with a progressive displacement towards a distal position in the following segments (distal portion / total length $=0.47$ in segment II, and 0.37 in the most posterior segments). Upper tooth $(\mathrm{U})$ longer than lower $(\mathrm{L})$ in segment II (U/L $=4.3 / 2.5 \mu \mathrm{m}$ ), gradually becoming of equal length in the median region, and the upper smaller than the lower in the posterior segments $(\mathrm{U} / \mathrm{L}=2.5 / 3.0 \mu \mathrm{m})$ (Fig. 4A).

REMARKS: The species $P$. breviseta may or may not present a proboscis, as is clearly illustrated by Marcus (1943, Fig. 101). The presence/absence of a proboscis is now recognised as a character that may be variable at an infrageneric or even infraspecific level within the Pristina genus, since Collado and Schmelz (2000) have included the Pristinella genus in synonymy with Pristina.

The question of long $v s$. short needle teeth can be a confusing character for identification purposes, since the length may be variable, as is shown in the studied individual (Fig. 4). The ratio of needle tooth length to the distal part of the needle (from the nodulus to the tip) varies between 0.25 and 0.1 ,

Table 5.- Several morphological features of Pristina breviseta from different sources. Abbreviations: s, number of segments.

Table 5.- Varios caracteres morfológicos de Pristina breviseta, extraído de diversas fuentes. Abreviaturas: s, número de segmentos.

\begin{tabular}{lccccc}
\hline Source & s & Hairs $(\boldsymbol{\mu m})$ & Needles $(\boldsymbol{\mu m})$ & Needle teeth U/L $(\boldsymbol{\mu m})$ & Ventral chaetae \\
\hline Aiyer (1925) & $35-120$ & up to 290 & 95 & - & $76-95$ \\
Marcus (1943) & 40 & $140-320$ & $45-70$ & $\approx 8.0$ & $62-71$ \\
Pujals (1985) & $37-55$ & $169-454$ & $85-135$ & $\approx 3.5-6.0$ & 62 \\
This study & 27 & $76-221$ & $40-46$ & $2.5-5.0$ & $48-58$ \\
P. rotundirostris & 32 & $97-128$ & $51-53$ & $\approx 2.0 *$ & $48-57$ \\
\hline
\end{tabular}

* measured from drawing (Grimm, 1985). 

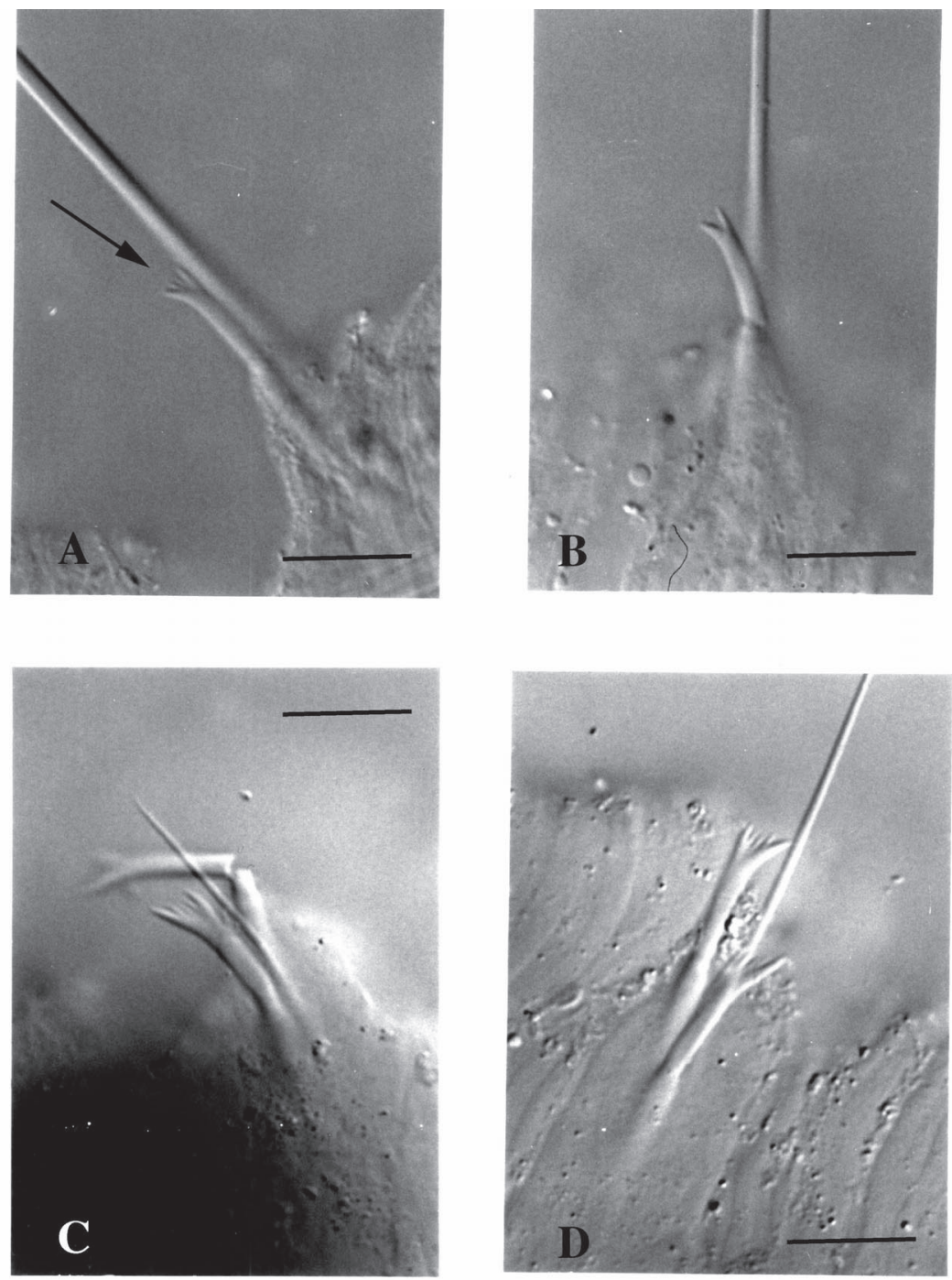

Fig. 5.- A. Pristina osborni, pectinated needle and hair-chaeta (arrow indicates the position of pectinations). B. Pristina osbor$n i$, non-pectinated needle. C. and D. Pristina sima, needles. Scale bars: $10 \mu \mathrm{m}$.

Fig. 5.- A. Pristina osborni, aguja pectinada y capilar (la flecha indica la posición de las pectinaciones). B. Pristina osborni, aguja no pectinada. C. and D. Pristina sima, agujas. Escala: $10 \mu \mathrm{m}$.

which is shorter than the relation of one third reported by Marcus (1943, Fig. 102C). A similar relationship (ca. 0.20) is present in the African species P. rotundirostris Grimm, 1985, which also has smooth hair chaetae and parallel needle teeth. However, in this species the ventral chaetae are more numerous per bundle and the length of teeth of ventral chaetae is described as equal.

Measurements of the chaetae reported here for $P$. breviseta are within the range or are smaller than those reported by other authors (Table 5). The length of ventral chaetae increases in the anterior segments of the studied specimen of $P$. breviseta, a fact that was also reported by Marcus (1943), although it is a common characteristic in many species of the genus Pristina. Immature specimens of $P$. breviseta can be distinguished from $P$. synclites by the length of the teeth in ventral chaetae, described as equal in P. synclites, and the upper longer than the lower in P. breviseta.

Pristina breviseta is widespread in North America (Brinkhurst, 1986) and it is also known in 


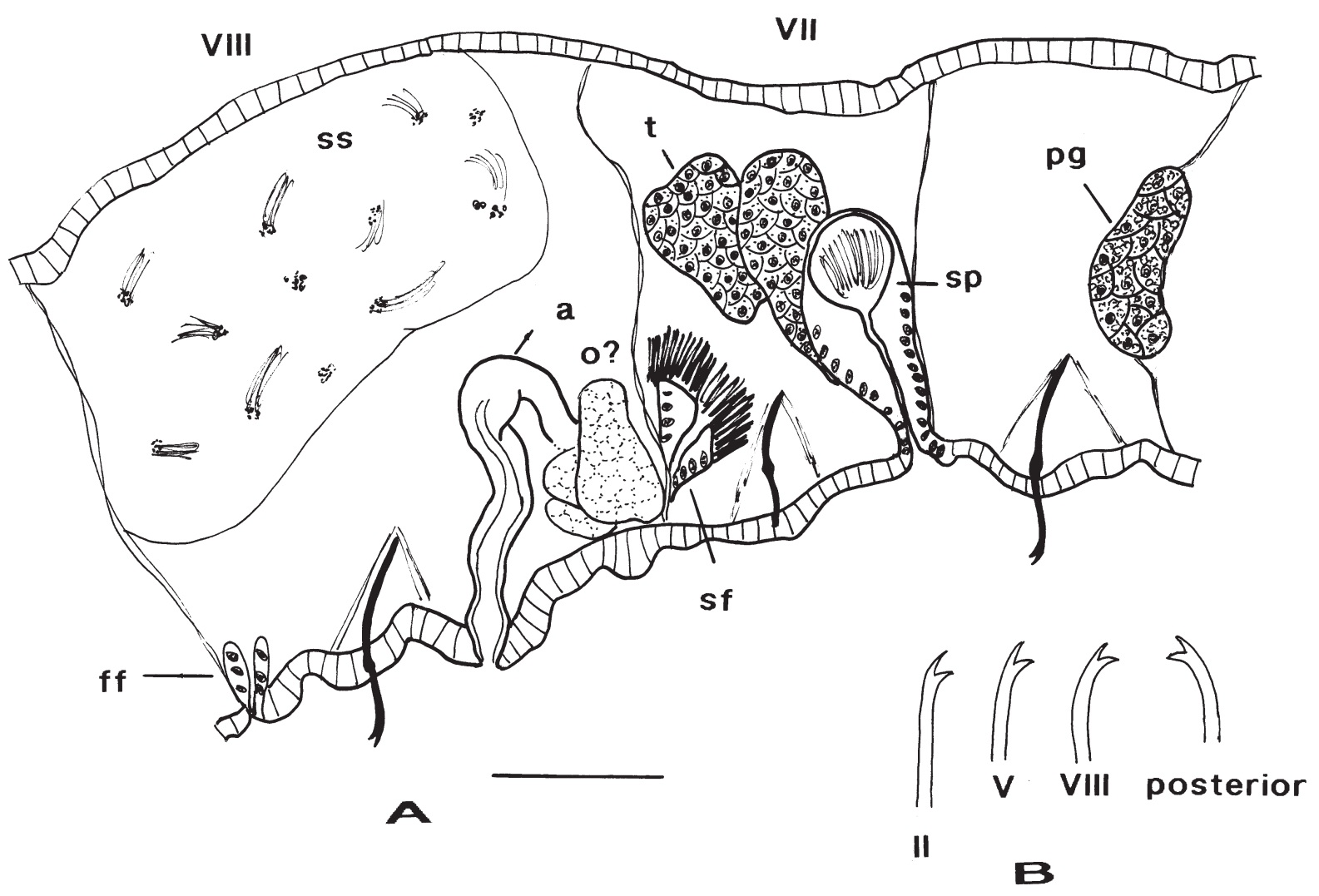

Fig. 6.- Pristina osborni, A. Reproductive apparatus. Abbreviations: a, atrium; ff, female funnel; o, ovary; pg, pharyngeal gland; sf, sperm funnel; sp, spermatheca; ss, sperm sac; t, testis. Scale bar: $25 \mu \mathrm{m}$. B. Ventral chaetae.

Fig. 6.- Pristina osborni, A. Aparato reproductor. Abreviaturas: a, atrio; ff, embudo femenino; o, ovario; pg, glándulas faríngeas; sf, embudo seminal; sp, espermateca; ss, saco espermático; t, testículo. Escala: $25 \mu \mathrm{m}$. B. Quetas ventrales.

Brazil (Marcus, 1943 and 1949), Argentina (Di Persia, 1980) and Martinique (P. breviseta?: Chagné and Giani, 1989).

Pristina osborni (Walton, 1906) (Figs. 5A, B \& 6) RECORDS: site 3 (5 ind.), 10 ( 1 ind.), 11(1 ind.), 22 (10 ind.), 28 (28 ind.)

DESCRIPTION: Number of segments, 19-22. Zone of scissiparity in segment 12-15. Diameter of the body in segment VIII, 88-108 $\mu \mathrm{m}$. Prostomium rounded, 46-95 $\mu \mathrm{m}$ long. Pharyngeal glands from (III) IV to V(VI). Stomach dilatation in segment VIII. One smooth hair chaeta (57-151 $\mu \mathrm{m}$ long, $c a .2 \mu \mathrm{m}$ width) and one or two needles per dorsal bundle. Bifid needles (25-37 $\mu \mathrm{m}$ long) of the same thickness as the hair chaetae; nodulus at about one third of the distal end (distal portion/total length $=0.31-0.37$ ); teeth diverging with upper tooth equal or slightly shorter (1.2$1.7 \mu \mathrm{m}$ long) and thinner than lower (1.7-3.1 $\mu \mathrm{m}$ long). In some individuals, some needles are pectinated by the presence of two intermediate teeth.

Ventral chaetae 3-4(5) per bundle in anterior segments (28-37 $\mu \mathrm{m}$ long), increasing in length in first segments of the body, and (2)3-4 in the posterior segments (32-41 $\mu \mathrm{m}$ long). Chaetae of segment II thinner than the following ones. Nodulus of ventral chaetae median in segment II, being gradually more distal towards the middle and posterior part of the body (distal portion/total length $=0.44-0.5$ in segment II up to $0.33-0.37$ in the most posterior segments). Upper (U) tooth longer than lower (L) in ventral chaetae of segment II $(\mathrm{U} / \mathrm{L}=2.8-3.2 / 1.8$ $2.2 \mu \mathrm{m}$ ), with a tendency towards an equal length in the following segments, and the upper shorter than the lower in the posterior ones $(\mathrm{U} / \mathrm{L}=1.8-2.0 / 2.0$ $2.2 \mu \mathrm{m})$.

Clitellum not clearly differentiated. One pair of spermathecal pores in segment VII (Fig. 6A). One 
pair of male pores in segment VIII. Tubular atria. Spermathecae are located in the most anterior part of the segment, close to the anterior septum. They are formed of a spherical ampulla (15 $\mu \mathrm{m}$ diameter) and a wide duct ( $23 \mu \mathrm{m}$ long, $15 \mu \mathrm{m}$ max. width). One pair of seminal funnels in septum VII/VIII which connect with atria. No modified genital chaetae.

REMARKS: Sperber (1948) stated the probable synonymy of $P$. minuta (Stephenson) and P. osbor$n i$ (Walton), an opinion shared by Brinkhurst and Kathman (1983). As P. minuta, the species has been reported in Texas (Harman, 1973) and Brazil (Marcus, 1943; Righi, 1973), and it has also been reported in Africa and Asia. The range of variability of the chaetae measurements is very similar for both species (Table 6).

There has been a considerable taxonomical confusion between $P$. sima and P. osborni, and a part of the reports of $P$. sima are probably due to the presence of $P$. osborni with pectinated needles. The presence or absence of intermediate teeth in the same individual in this species was first reported by Loden and Harman (1980) who pointed out the possibility of misidentification of $P$. osborni as $P$. sima because of the occasional presence of pectinated needles. The original description of $P$. sima by Marcus (1944, Fig. 59D) shows the typical needle bent in its distal third, with relatively long teeth, distal thinner and shorter than lower, while needles are straight with short and about equal teeth in $P$. osborni. One of the needles drawn by Grimm
(1986) for African P. osborni populations could be of the sima-type. The needles drawn for P. sima by Varela (1990) in individuals from Argentina are of the osborni-type. Harman et al. (1988) and Brinkhurst and Marchese (1989) regarded P. osbor$n i$ as a probable synonym of $P$. sima and $P$. minuta. On the other hand, it is my opinion that the form and size of the needles support the independent status of P. sima (see remarks of this species below).

Pristina osborni has been reported in Central and South America (Costa Rica: Harman, 1982; Martinique: Chagné and Giani, 1989; Argentina: Di Persia, 1980; Marchese, 1986; Perú: Harman et al., 1988; Coates and Stacey, 1994) and North America (Great Lakes: Spencer, 1980; Texas: Davis, 1982) and also in Europe and Africa.

\section{Pristina sima (Marcus, 1944) (Fig. 5C, D)} RECORDS: site 35 (17 ind.)

DesCription: Number of segments, 23-24. Diameter of the body in segment VIII, 101-104 $\mu \mathrm{m}$. Prostomium rounded, 54-79 $\mu \mathrm{m}$ long. One smooth hair chaeta (79-180 $\mu \mathrm{m}$ long) and one or two needles (27-42 $\mu \mathrm{m}$ long) per dorsal bundle. The length of hair chaetae increase from segment II to V (117$183 \mu \mathrm{m})$, in the middle region they are 154-167 $\mu \mathrm{m}$ long, and they shorten in the most posterior segments (to $51 \mu \mathrm{m}$ at most). Needles are not straight but bayonet-shaped, with well-marked nodulus at about one third of the distal end (distal portion / total length $=0.30-0.35)$. Bifid needles with teeth

Table 6.- Several morphological features of Pristina osborni from different sources. Abbreviations: L, lower tooth, s, number of segments, U, upper tooth.

Tabla 6.- Varios caracteres morfológicos de Pristina osborni, extraído de diversas fuentes. Abreviaturas: L, diente inferior, s, número de segmentos, $\mathrm{U}$, diente superior.

\begin{tabular}{lccccc}
\hline Source & $\mathbf{s}$ & Hairs $(\boldsymbol{\mu m})$ & Needles $(\boldsymbol{\mu m})$ & Needle teeth U/L $(\boldsymbol{\mu m})$ & Ventral chaetae \\
\hline Sperber (1948)§ & $15-16$ & 145 & 50 & "remote" & - \\
Davis (1982) & - & $92-113$ & $30-35$ & diverg. equal teeth & $35-45^{*}$ \\
Grimm (1990) & $16-27$ & $73-128$ & $26-39$ & $\approx 2$, equal & $30-44$ \\
Harman (1982) & - & up to 190 & $30-45$ & - & $38-48$ \\
Harman et al.(1988) & - & $80-112$ & $25-30$ & - & $30-40$ \\
Sperber (1948) minuta & - & $80-120$ & $30-35$ & equal & $30-40$ \\
Harman (1973) minuta & - & $77-105$ & $33-37$ & - & $33-37$ \\
Grimm (1974) minuta & - & $70-120$ & $27-47$ & $1.0-2.7 / 1.2-3.0 * *$ & $35-41$ \\
Marcus (1943) minuta & - & $80-90(120)$ & $30-35$ & $\approx 0.8$, equal & $30-40$ \\
Righi (1973) minuta & $18-22$ & $82-191$ & $30-45$ & $1.6-2.7 / 2.5-3.3$ & $35-51$ \\
Varela (1990) sima & - & $100-166$ & $35-48$ & $\approx 30$ & $40-60$ \\
This study & $19-22$ & $57-151$ & $25-37$ & $1.2-1.7 / 1.7-3.1$ & $28-41$ \\
\hline \& From description by Walton (1906). & & & & \\
* Increasing length posteriad. & & & & \\
** Measures taken from drawing, in Grimm (1974); Fig. 5. & & &
\end{tabular}


diverging, upper tooth shorter and thinner than lower (U/L: $2.2 / 2.8-3.9 \mu \mathrm{m})$, and all pectinated (3 intermediate teeth). Ventral chaetae 4-6 per bundle in anterior segments, and 4 (rarely 3 ) in the posterior segments (34 to $45 \mu \mathrm{m}$ long); nodulus located between one third and one half of the distal end of the chaetae (distal portion /total length $=0.36-0.43$ ) and a clear tendency in the size, from anterior to posterior chaetae is not observed. Upper tooth longer than lower in ventral chaetae of segment II, and smaller in posterior ventral bundles.

REMARKS: The presence of pectination in the needles is a constant in the studied collection. The number of the intermediate teeth in the needles is variable in some studied populations (e.g. 1 to 3 : Rodriguez, 1984; 2 or 3: Martínez-Ansemil and Giani, 1980). Ercolini's description (1969) includes the presence of denticulate hair chaetae, in contrast to Marcus's description (1944), Martinez-Ansemil and Giani (1980), Grimm (1990) and this study.

The specimen reported by Davis (1982) is probably a tubificid as can be judged from the shape of the needles (sigmoids and with longer distal teeth in needles) and their size (approx. $71 \mu \mathrm{m}$ long). Varela (1990) reported $P$. sima from Argentina; however, this material is probably P. osborni. Loden and Harman (1980) proposed a potential relation of $P$. sima with $P$. rosea-group species, due to the difference in length of needle teeth. Brinkhurst and Marchese (1989) suggested the synonymy of $P$. sima and $P$. minuta with $P$. osborni. However, $P$. sima can be well separated from these species by the characteristic bayonet-like form of the needles, with teeth longer and markedly unequal compared with those in $P$. osborni/minuta (compare data in Tables 6 and 7).

Pristina sima has been reported by several authors in Africa, Europe and America. It has been found in North America (N. York: Strayer and O'Donnell,
1988) and Central and South America (Martinique: Chagné and Giani, 1989; Guyana: Stacey and Coates, 1996; Brasil: Marcus, 1944; Argentina: in Brinkhurst and Marchese, 1989; Chile: Gluzman, 1990). Interestingly, the species has been reported in both freshwater and estuarine brackish water (MartínezAnsemil and Giani, 1980 and 1982). This is the first report of the species in Cuba.

\section{Pristina sp.}

RECORDS: site 10 (1 ind.)

Description: Number of segments, 15. Prostomium rounded, $15 \mu \mathrm{m}$ long. Diameter of the body, $212 \mu \mathrm{m}$, at segment VIII. From segment II onwards, dorsal bundles composed by one serrated hair chaeta and one or two simple-pointed needles. Hair chaetae, $1.5 \mu \mathrm{m}$ thick and 76-190 $\mu \mathrm{m}$ long, increasing in length in the first anterior segments. Hair chaetae of segment III with fine serrations, 2$2.5 \mu \mathrm{m}$ apart. Needles without nodulus, hair-like, ca. $2 \mu \mathrm{m}$ thick at their base, increasing in length backwards.

Ventral chaetae very variable in number, differing in number also in the bundles of the same segment. Ventral chaetae of segment II longer than the following ones, and thickness is $c a .2 \mu \mathrm{m}$, all along the body. Tooth length is variable within the chaetae of the same segment, the upper tooth being longer, equal or shorter than the lower in anterior segments, and shorter in posterior ones. Nodulus in ventral chaetae median or slightly distal in segments II and III (distal portion / total length $=0.43-0.50$ ) and distal in the following segments $(0.34-0.41)$.

REMARKS: The only individual found does not have a proboscis. However, the characteristics of the chaetae resemble those of the Pristina species with strongly serrated hair chaetae, like Pristina proboscidea Beddard, 1896 or some variants of $P$. longiseta Ehrenberg, 1828.

Table 7.- Several morphological features of Pristina sima from different sources. Abbreviations: L, lower tooth; s, number of segments; U, upper tooth.

Tabla 7.- Varios caracteres morfológicos de Pristina sima, extraídos de diversas fuentes. Abreviaturas: L, diente inferior; s, número de segmentos; U, diente superior.

\begin{tabular}{|c|c|c|c|c|c|}
\hline Source & $\mathbf{s}$ & Hairs $(\mu \mathrm{m})$ & Needles $(\mu \mathrm{m})$ & Needle teeth $\mathrm{U} / \mathrm{L}(\mu \mathrm{m})$ & Ventral chaetae \\
\hline Marcus (1944) & 17 & $90-140$ & $30-35$ & $3.5 / 4.7 \S$ & $25-35$ \\
\hline Ercolini (1969) & - & $117-174$ & $20-25$ & $3 / 4.5$ & $28-39$ \\
\hline Rodriguez, 1984 & 14 & $64-110$ & $31-32$ & $1.8-2.5 / 3.1-3.7$ & $21-36$ \\
\hline This study & $23-24$ & $79-180$ & $27-42$ & 2.2/2.8-3.9 & $34-45$ \\
\hline
\end{tabular}

*mean values.

$\S$ From drawing in Marcus 1944: Fig. 59D. 
Pristina gr. rosea (sensu Grimm, 1990)

RECORDS: site 5 (1 ind.), 12 (1 ind.), 21 (1 ind.), 26 (1 ind.)

Dero (Aulophorus) lodeni Brinkhurst, 1986

RECORDS: site 26 (1 ind.)

REMARKS: The species has already been reported in North and South America (USA, Surinam, Guyana, Brazil, Paraguay and Argentina) (Stacey and Coates, 1996), and this is the first record for Central America.

\section{Undetermined Naididae}

Records: site 9 (1 ind.), 17 (1 ind.)

\section{ALLUROIDIDAE}

Brinkhurstia americana (Brinkhurst, 1964) (Fig. 7) RECORDS: site 2 (1 mature, 4 immature)

DESCRIPTION OF THE MATURE SPECIMEN: $9 \mathrm{~mm}$ long, $0.6 \mathrm{~mm}$ diameter. Incomplete worm of 88 segments. Prostomium $93 \mu \mathrm{m}$ long. One pair of simple-pointed chaetae per bundle in every segment, sigmoid, 105-142 $\mu \mathrm{m}$ long and about $6 \mu \mathrm{m}$ wide (Fig. 7C), except in ventral bundles of segment XIII where they are absent. Clitellum from the line of chaetae of segment XIII to segment XIV. Epithelium 6 to $14 \mu \mathrm{m}$ high in the dorsal preclitellar region of the tegument, $21-24 \mu \mathrm{m}$ in the clitellar region; ventral epithelium usually thicker (10$26 \mu \mathrm{m}, 21-29 \mu \mathrm{m}$ in the clitellum); in the postclitellar region, epithelium very thin $(3 \mu \mathrm{m})$. Longitudinal musculature 30 to $48 \mu \mathrm{m}$ thick. One pair of male pores ventrally in segment XIII, in line with ventral chaetae (Fig. 7B). Single spermathecal pore opens mid-dorsally, in segment IX.

Septal glands in segments V to IX. Intestine from VIII. One pair of testes in the anterior part of segment X, one pair of ovaries in the anterior part of segment XIII. Over one of the testes, a sperm sac could be seen. Egg sac extends backwards to XVII. Sperm funnels open down septum X/XI (Fig. 7A). Male duct, "atria" according to Brinkhurst (1964) and Righi et al. (1978) descriptions, and "prostate" after Omodeo (2001), long and tubular, convoluted in segment XIII (Fig. 7B). Three different sections can be distinguished in the male duct: a first section formed by finely granulated cells, about $170 \mu \mathrm{m}$ long, 30-62 $\mu \mathrm{m}$ diameter; a second non-granulated section, about $700 \mu \mathrm{m}$ long, $25-45 \mu \mathrm{m}$ diameter, formed by very dense cells; and a third narrow tubular section, about $550 \mu \mathrm{m}$ long, $18 \mu \mathrm{m}$ diameter. The second section and part of the first are covered by a diffuse glandular layer (6-16 $\mu \mathrm{m}$

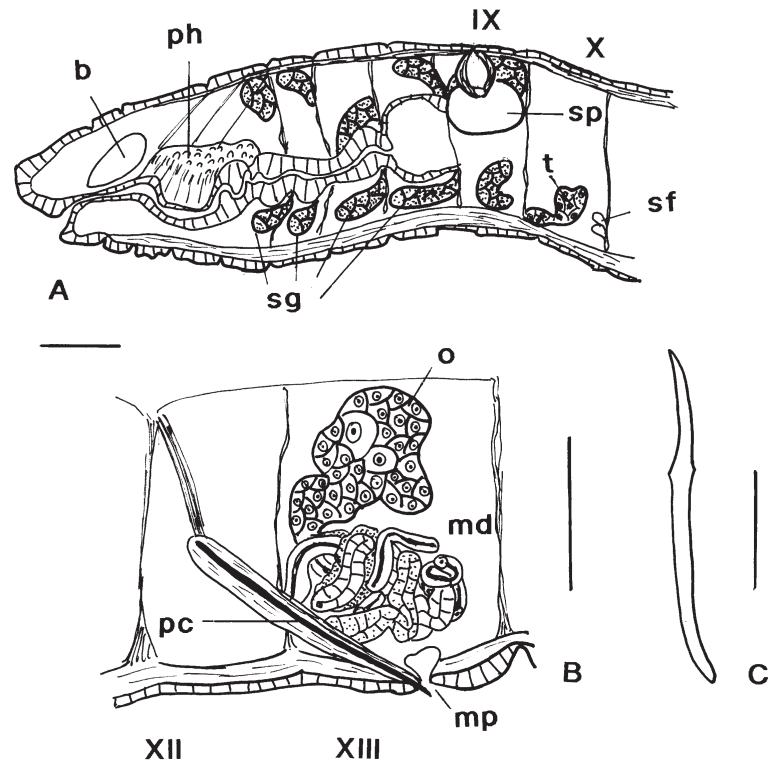

Fig. 7.-Brinkhurstia americana. A. and B. Anterior region of the body and reproductive apparatus. C. Somatic chaeta. Scale bar: $200 \mu \mathrm{m}$ in A and B, $50 \mu \mathrm{m}$ in C. Abbreviations: b, brain; md, male duct; $\mathrm{mp}$, male pore; o, ovary; pc, penial chaeta; $\mathrm{ph}$, pharynx; sf, sperm funnel; sg, septal glands; sp, spermatheca; t, testis.

Fig. 7.-Brinkhurstia americana. A y B. Región anterior del cuerpo y aparato reproductor. C. queta somática. Abreviaturas: $\mathrm{b}$, cerebro; md, conducto masculino; $\mathrm{mp}$, poro masculino; ovario; pc, queta penial; ph, faringe; sf, embudo seminal; sg, glándulas septales; sp, espermateca; t, testículo.

high), made of cells containing large granules, which form some masses between adjacent coils. The duct which connects the sperm funnel with the ectal section of the male duct was not observed, probably broken during dissection.

One pair of penial chaetae (380-400 $\mu \mathrm{m}$ long, $13 \mu \mathrm{m}$ max. width), simple-pointed, associated with the male pores, into a muscular sheath $(36 \mu \mathrm{m}$ max. width) in segments XII and XIII. A thick retractor muscle (up to $27 \mu \mathrm{m}$ thick) joins the longitudinal musculature of the tegument in the anterior part of segment XII to the proximal part of the muscular sheath which contains the penial chaeta.

One single spermatheca in the dorsal part of segment IX, formed by a compressed spherical ampulla (236 $\mu \mathrm{m}$ max. diameter) which opens in the mid-dorsal line through a short vestibulum (about $90 \mu \mathrm{m}$ long), with thick muscular layer (max. $25 \mu \mathrm{m}$ thick). 
REMARKS: There are few differences with previous descriptions of the species. The penial chaetae are longer than those described by Brinkhurst and Jamieson (1971) (115 $\mu \mathrm{m}$ long, $18 \mu \mathrm{m}$ max. diameter), but shorter than the description by Omodeo and Coates (2001) from Guyana (>560 $\mu \mathrm{m}$ by $12.2 \mu \mathrm{m})$. Compared with the original description (Brinkhurst, 1964), the position of the spermathecal pore is median rather than anterior in segment IX. The form of the spermatheca resembles that described by Omodeo and Coates (2001) more than that by Brinkhurst (1964). Sperm sacs have not been reported in previous descriptions.

The type specimens studied by Brinkhurst (1964) were from Argentina. The species has also been reported in Brazil (Righi et al., 1978) and Guyana (Stacey and Coates, 1996; Omodeo and Coates, 2001). Therefore, the new finding of the species in Coiba island, reflects an extensive distribution of the species Brinkhurstia americana in South and Central America.

\section{ENCHYTRAEIDAE}

\section{Marionina gr. subterranea}

RECORDS: site 1 (15 ind.), 28 (2 ind.)

REMARKS: the worms lack lateral bundles of chaetae all along the body and they have 2 chaetae per ventral bundle, simple, straight and bent in their proximal end.

\section{Enchytraeus gr. minutus}

RECORDS: site 10 (1 ind.), 19 (1 ind.)

\section{Undetermined Enchytraeidae}

RECORDS: Site 4 (1 immature ind.), 5 (1 fragment), 6 (3 immature ind.), 7 ( 1 immature ind.), 10 (5 immature ind.), 12 (2 immature ind.), 13 (3 immature ind.), 14 (2 ind.), 16 (1 mature ind.), 18 (2 mature ind.), 19 (1 immature ind.), 21 (1 immature ind.), 23 (1 immature ind.), 24 (1 immature ind.), 28 (1 immature ind.), 29 (17 immature ind.), 31 ( 3 immature ind., 2 mature ind.), 33 (4 immature ind.), 34 (1 immature ind.), 35 (4 immature ind.)

In the collection, there are also a few aelosomatids (Aelosoma sp.): site 32 (9 ind.), and some undetermined megadrile oligochaetes: site 8 ( 2 ind.), 9 (1 ind.), 10 (5 ind.), 14 ( 1 ind.), 16 ( 1 ind.) 19 (1 ind.), 20 ( 1 ind.), 24 ( 1 ind.), and 29 ( 3 ind.).

\section{Discussion}

The freshwater oligochaete fauna of Central America and the Caribbean region has been previously studied by several authors. The oligochaete families Naididae, Opistocystidae and the aphanoneuran Aeolosomatidae have received special attention through contributions by Michaelsen (1933) and Harman (1965 and 1982), who reported twenty one species from Central America (Salvador, Costa Rica, Guatemala, Nicaragua and Honduras). More recently, Dumnicka (1983 and 1986) studied a collection from subterranean habitats in several Caribbean islands and North Venezuela, reporting a total of four tubificids and twelve naidids. Botea (1983) studied three collections of subterranean oligochaetes and aelosomatids from Cuba and provided a list of 34 species, of which 17 were described as new to Science, although descriptions are quite poor and incomplete. A posterior study by the same author reported 15 species of aquatic oligochaetes and aelosomatids from subterranean waters in Venezuela, of which 3 were new to Science (Botea, 1987). Medeiros and Neves (1982), Coates and Stacey (1994), and Stacey and Coates (1996) reported about 50 taxa from Bonhaire island and Guyana, respectively. More recently, Chagné and Giani (1998) have reported 35 species from Martinique. The diversity of the fauna in the region is relatively large taking into account the limited number of studies, and more than one hundred taxa have been reported so far. In this context, the taxa identified from Coiba island in the present study should be regarded as a preliminary list of the oligochaete species, which will undoubtedly be amplified with further studies.

The absence of a cosmopolitan fauna in the samples is in concordance with the general characteristics of the sites in Coiba island, which is practically undisturbed and unpolluted. It will be also interesting to determine in future studies if any important differences in the distribution of oligochaete fauna exists between the Pacific islands and the Atlantic Caribbean islands. The present study would seem to suggest that such differences are minimal.

\section{ACKNOWLEDGEMENTS}

I am indebted to Dr. Ana Camacho and Dr. Antonio GarcíaValdecasas from the National Museum of Natural Sciences of Madrid for placing the collection at my disposal. The author would also like to thank the agency ACTS (Academic Consulting and Translating Services http://www.euskalnet.net/acts) for having revised the English version of this paper.

\section{References}

BoteA, F., 1983. Oligochètes souterraines de Cuba. In: Résultats des expéditions biospéologiques cubanoroumaines à Cuba, IV: 19-38. 
BoteA, F., 1987. Oligochaeta from Venezuela. In: Fauna hipogea y hemiedáfica de Venezuela y de otros países de America del Sur, 6. Academii Republicii Socialiste România (Bucarest): 67-72.

BRINKHURST, R. O., 1964. A taxonomic revision of the Alluroididae (Oligochaeta). Proceedings of the Zoological Society of London, 142: 527-536.

BrinkHURST, R. O., 1971. Naididae. In: Brinkhurst, R. O. and Jamieson, B. G. M. (eds), Aquatic Oligochaeta of the World. Oliver \& Boyd, Edinburgh: 304-443.

BRINKHURST, R. O., 1979. A new species of Limnodrilus (Oligochaeta: Tubificidae) from Jamaica. Proceedings of the Biological Society of Washington, 92(1): 42-44.

BrinkHURST, R. O., 1986. Guide to the Freshwater Aquatic Microdrile Oligochaetes of North America. Canadian Special Publication of Fisheries and Aquatic Sciences, 84: 1-259.

Brinkhurst, R. O. \& JAmieson, B. G. M., 1971. Aquatic Oligochaeta of the World. Oliver \& Boyd. Edinburgh. 860 pp.

Brinkhurst, R. O. \& Kathman, R. D. A., 1983. A contribution to the taxonomy of the Naididae (Oligochaeta) of North America. Canadian Journal of Zoology, 61: 2307-2312.

Brinkhurst, R. O. \& MARChese, M., 1989. Guía para la identificación de Oligoquetos acuáticos continentales de Sud y Centro America. Colección CLIMAX, $\mathrm{N}^{\mathrm{o}} 6$ ( $2^{\mathrm{a}}$ Edición). Asociación Ciencias Naturales del Litoral (ACNL). Sto. Tomé, Argentina. 207 pp.

Brinkhurst, R. O. \& Wetzel, M. J., 1984. Aquatic Oligochaeta of the World: Supplement. A catalogue of new freshwater species, descriptions and revisions. Canadian Technical Report on Hydrography and Ocean Sciences, $N^{\circ}$ 44, Sidney, BC, Canada, 101 pp.

Chagné, P. \& Giani, N., 1998. Taxinomie et faunistique des Oligochètes aquatiques de la Martinique. Bulletin de la Société d'Histoire Naturelle de Toulouse, 134: 21-32.

Coates, K. A. \& Stacey, D. F., 1994. Oligochaetes (Naididae, Tubificidae, Enchytraeidae and Alluroididae) of Guyana, Peru and Ecuador. In: T. B. Reynoldson and K. A. Coates (eds.), Developments in Hydrobiology. Aquatic Oligochaete Biology $V$, Hydrobiologia, 278: 79-84.

Collado, R. \& Schmelz, R. M., 2000. Pristina silvicola and Pristina terrena spp. nov., two new soil-dwelling species of Naididae (Oligochaeta, Annelida) from the tropical rain forest near Manaus, Brazil, with comments on the genus Pristinella. Journal of Zoology (London), 251: 509-516.

DAVIS, J. R., 1982. New records of aquatic Oligochaeta from Texas, with observations on their ecological characteristics. Hydrobiologia, 96: 15-31.
Di Persia, D. H., 1980. The Aquatic Oligochaeta of Argentina: current status of knowledge. In: R. O. Brinkhurst and D. G. Cook (eds.), Aquatic Oligochaete Biology. Plenum Press. New York: 79-113.

DUMNICKA, E., 1983. Amsterdam expedition to the West Indian Islands, Report 30. Tubificidae (Oligochaeta) from subterranean waters, with description of two new genera. Bijdragen tot der Dierkunde, 53: 255-261.

DuMNICKA, E., 1986. Naididae (Oligochaeta) from subterranean waters of West Indian islands- distribution, taxonomic remarks and description of a new species. Bijdragen tot der Dierkunde, 56: 267-281.

Ercolini, A., 1969. Su alcuni Aeolosomatidae e Naididae della Somalia (Oligochaeta, Microdrili). Monitore Zoologico Italiano (N.S.), Suppl. III, 2: 9-36.

García-Valdecasas, A., Camacho, A. I., Aranzadi, P. \& Bello, E., 1997. Las aguas dulces de la isla de Coiba (Panamá). In: S. Castroviejo (ed.), Flora y Fauna del Parque Nacional de Coiba (Panamá) Inventario Preliminar. AECI (Agencia Española de Cooperación Internacional): 108-151.

Gluzman, C., 1990. New information on aquatic Oligochaeta of Chile. Studies on Neotropical Fauna and Environment, 25: 89-92.

Grimm, R., 1985. Beitrage zur Systematik der Africanischen Naididae (Oligochaeta).I. Beschreiben von vier neuen Arten. Mitteilungen aus dem hamburgischen Zoologischen Musuem und Institut, 82: 101108.

GrimM, R., 1986. Beiträge zur Systematik der Africanischen Naididae (Oligochaeta). III. Untersuchungen zur qualitativen und quantitativen Chaetotaxonomie der Naididae. Mitteilungen aus dem hamburgischen Zoologischen Musuem und Institut, 83: 101-115.

GrimM, R., 1990. Beiträge zur Systematik der Africanischen Naididae (Oligochaeta). VII. Naidinae (Teil 3) und Stylarinae. Mitteilungen aus dem hamburgischen Zoologischen Musuem und Institut, 87: 123-148.

Harman, W. J., 1965. A key to the genus Slavina (Oligochaeta: Naididae) with a description of a new species from Costa Rica. Annals and Magazine of Natural History, 8(13): 565-568.

Harman, W. J., 1966. Some aquatic oligochaetes from Mississippi. American Midland Naturalist, 76: 239242.

HARMAN, W. J., 1973. New species of Oligochaeta (Naididae) with additional distributional records from Oklahoma and Texas. Southwestern Naturalist, 18: 151-164.

Harman, W. J., 1974. The Naididae (Oligochaeta) of Surinam. Zoologische Verhandelingen (Leiden), 133: $1-36$. 
HARMAN, W. J., 1982. The aquatic Oligochaeta (Aeolosomatidae, Opistocystidae, Naididae) of Central America. Southwestern Naturalist, 27: 287-299.

Harman, W. J., Loden, M. S. \& Davis, J. R., 1979. Aquatic Oligochaeta new to North America with some records of species from Texas. Southwestern Naturalist, 24: 509-525.

Harman, W. J., Brinkhurst, R. O. \& Marchese, M., 1988. A contribution to the taxonomy to the aquatic Oligochaeta (Naididae) of South America. Canadian Journal of Zoology, 66: 2233-2242.

LODEN, M. S. \& HARMAN, W. J., 1980. Ecophenotypic variation in setae of Naididae (Oligochaeta). In: R. O. Brinkhurst and D. G. Cook (eds.), Aquatic Oligochaete Biology. Plenum Press. New York: 33-39.

MARCuS, E., 1943. Sobre (Oligochaeta) Naididae do Brasil. Boletim da Faculdade de Filosofia, Ciências e Letras, Universidade de São Paulo, 32(7): 3-247.

Marcus, E., 1944. Sôbre Oligochaeta límnicos do Brasil. Boletim da Faculdade de Filosofia, Ciências e Letras, Universidade de São Paulo, 43(8): 5-136.

MARCus, E., 1949. Further notes on naidids and tubificid from Brazil. Comunicaciones Zoológicas del Museo de Historia Natural de Montevideo, 3(51): 1-15.

MARCHESE, M., 1986. Nuevos aportes al conocimiento de los oligoquetos del río Paraná medio y algunos tributarios. Studies on Neotropical Fauna and Environment, 21: 231-249.

MartíneZ-Ansemil, E. \& Giani, N., 1980. Premières données sur les oligochètes aquatiques de la Péninsule Ibérique. Annales de Limnologie, 16: 45-54.

MartíneZ-Ansemil, E. \& GiAni, N., 1982. Contribución al conocimiento del género Pristina (Oligochaeta, Naididae) en la Península Ibérica. Boletín de la Real Sociedad Española de Historia Natural (Sección Biológica), 80(3-4): 249-260.

MartíneZ-Ansemil, E. \& Giani, N., 1986. Algunos oligoquetos acuáticos de Bolivia. Oecologia Aquatica, 8: $107-115$

Medeiros, L. R. A. \& Neves, R. S., 1982. Peloscolex coiree sp. n. (Oligochaeta, Tubificidae) da Ilha de Bonaire (Antilhas Holandesas). Revista Brasileira de Biologia, 42(1): 177-179.

Michaelsen, W., 1933. Süss und BrackwasserOligochäten von Bonaire, Curaçao und Aruba. Zoologische Jahrbücher, Abteilung für Systematik, Ökologie und Geographie der Tiere, 64: 327-356.

OmodeO, P. \& COATES, K., 2001. New alluroidids (Annelida, Clitellata) from Guyana. In: P. Rodríguez and P. F. M. Verdonschot (eds.), Developments in Hydrobiology. Aquatic Oligochaete Biology VIII. Hydrobiologia, 463: 39-47.

Pujals, M.A., 1985. Especies de los géneros Pristina Ehrenberg, 1828 y Bratislavia Kosel, 1976 (Oligochaeta, Naididiae) en la provincia de Buenos Aires,
Argentina. Studies on Neotropical Fauna and Environment, 20(4): 203-210.

Righi, G., 1973. On Pristina minuta (Oligochaeta, Naididae) from Brazilian soil and its epizoic Rhabdostyla pristinis sp. n. (Ciliata, Epistylidae). Zoologischer Anzeiger, 191(5-6): 295-299.

Righi, G., Ayres, I. \& Bittencourt, E. C. R., 1978. Oligochaeta (Annelida) do Istituto Nacional de Pesquisas da Amazônia. Acta Amazonica, 8: 1-49.

Rodríguez, P., 1984. Estudio taxonómico de los oligoquetos acuáticos del País Vasco y cuenca alta del Ebro y caracterización de las comunidades de los ríos Nervión y Butrón (Vizcaya). Unpublished Doctoral Thesis. Universidad del País Vasco UPV/EHU.

Rodríguez, P., 1999. Monopylephorus camachoi nov. sp., a new rhyacodriline worm (Tubificidae, Clitellata) from Coiba Island, on the east Pacific Coast of Panamá. Hydrobiologia, 406: 49-55.

Rodríguez, P. \& ARMAS, J. C., 1983. Contribution à la connaissance de la faune d'oligochètes aquatiques du Pays Basque et zones limitrophes. Annales de Limnologie, 19: 93-100.

Spencer, D. R., 1980. The aquatic Oligochaeta of St. Lawrence Great Lakes Region. In: R. O. Brinkhurst and D.G. Cook (eds.), Aquatic Oligochaete Biology. Plenum Press. New York: 115-164.

SPERBER, C., 1948. A taxonomical study of the Naididae. Zoologiska Bidrag fran Uppsala, 28: 1-296.

StaceY, D. F. \& CoATES, K. A., 1996. Oligochaetes (Naididae, Tubificidae, Opistocystidae, Enchytraei-dae, Sparganophilidae and Alluroididae) of Guyana. In: K. A. Coates, T. B. Reynoldson and T. B. Reynoldson (eds.), Developments in Hydrobiology. Aquatic Oligochaete Biology VI. Hydrobiologia, 334: 17-29.

Strayer, D. \& O’Donell, E., 1988. Aquatic Microannelids (Oligochaeta and Aphanoneura) of underground waters of Southeastern New York. American Midland Naturalist, 119(2): 327-335.

VARELA, M. E., 1990. Taxonomic and ecological notes about some oligochaetes of freshwater of Northeastern Argentina. 1. Naididae. Studies on Neotropical Fauna and Environment, 25(4): 223-233. 